This is a pre-copy-editing, author-produced PDF of an article accepted for publication in Nations and Nationalism following peer review. The definitive publisher-authenticated version. Zuev D. (2010), Movement Against Illegal Immigration: analysis of the central node in the Russian extreme-right movement. Nations and Nationalism, 16(2): 261-284 is available online at: http://dx.doi.org/10.1111/j.1469-8129.2010.00430.x 


\section{Movement Against Illegal Immigration: analysis of the central node in the Russian extreme-right movement}

\section{Dennis Zuev \\ CIES-ISCTE}

tungus66@gmail.com

\section{ABSTRACT:}

The goal of this article is to analyze political communication style of the Movement Against Illegal Immigration (Dvizheniye Protiv Nelegalnoy Immigrazii - DPNI), which is one of the central nodes in the Russian extremeright movement web-network. In the article political communication style of the organization is investigated at two levels - the presentation of online identity and the presentation of offline identity. Online self-presentation is studied by means of the qualitative analysis of the incoming links (position in the web-network) and the internal structure of the website. DPNI is conceptualized as a new type of political organization based on networking principle allowing flexible membership and based on interplay of its online and offline self-presentations. The study provides insights into how the new media become embedded in the political communication of extreme-right political organizations in Russia.

KEYWORDS: Movement Against Illegal Immigration, DPNI, Russia, Internet, 
political communication style, extreme-right movement

\section{Introduction}

The recent results of the studies on interethnic relations in Russia demonstrate that the balance between the social strata that verbalize "disliked" ethnic groups and those which don't is very fragile (Puuronen et al. 2007; Zuev 2007), the expression of xenophobia and ethnic prejudice has intensified and beliefs of the "non-Russian dominance" in Russia have increased (Gudkov and Dubin 2005: 17-18). The survey results are confirmed by the number and scale of interethnic conflicts between the Russian and non-Russian population (the most public case being that of Kondopoga in 2006).

Despite ethnic tensions and proliferation of ethnic and racial violence, Russia may seem to be the case where single issue of immigration has little effect on the success of the extreme right ${ }^{1}$. Taking into account the fact that high levels of immigration in Western Europe seem to have increased support for right-wing parties, increased hostility towards immigrants and produced violent right-wing behavior (McLaren 2001: 81) one can assume that with the growth of immigration in Russia and aggravation of the socioeconomic situation in the country the tensions will become more acute. This will lead to expansion of the political space for the political actors wishing to capitalize on immigration issue. Therefore it makes a timely research task to distinguish main actors in the extreme-right politics, their coalition and 
communication strategies.

The developments in the Eastern part of the extreme-right party family have been analyzed in Braun and Scheinberg 1997; Eatwell 2002; Hanley et al. 2008; Minkenberg 2002; Mudde 2005; Ramet, 1999; Szcocs 1998. Studies of ultra nationalism have been one of the most prominent trends of political research concerning Russia (Parland 2005: 14-15), with some scholars analyzing it in the vein of fascist ideology (Shenfiled 2001; Umland 2005, 2006). Although, the term "fascist" is becoming obsolete for analytic purposes (Minkenberg 2000) it remains an important discursive element of the political communication in Russia.

The studies of Russian extreme right movement organizations can be divided into two time periods of the movement development. ${ }^{2}$ The first "wave" of studies (Hockenos 1993; Likhachev 2002; Mathyl 2002; Sokolov 2004, 2006; Tolz 2003; Williams and Hanson: 1999) deals primarily with the cases of populist-opportunist parties (LDPR) or extra-parliamentary extreme-right organizations (Russian National Unity), organizations with mixed leftist and rightist ideology (NBP) or the phenomenon of "organized intolerance" (for detailed definition see Ramet 1999) in Russia. The second "wave" of studies concentrates on development of extreme-right movement in essentially new subcultural context (Aitamurto 2007) and new emerging political opportunity structure (Varga 2008). The second group of studies deals with the New extreme-right movement which is different from the historical fascism (old extreme-right with predominantly antisemitic ideology). This group to some 
extent emulates the tactics of the West-European extreme-right parties and structure-wise combines "groupuscular" (Griffin 2004) leaderless network structure with small-scale extra-parliamentary parties, often headed by the Duma deputies.

Non-party organizations in the new extreme-right in Russia and their political communication styles are a relatively under-researched topic. This work is an exploratory study of one of the leading movement organizations Movement Against Illegal Immigration (DPNI), which has only been briefly mentioned in studies by Aitamurto (2007) and Varga (2008). The idea of the study is to conceptualize how the Internet and the Internet-enabled resources become embedded in the political communication style of a political organization. The goal of this study is to demonstrate how the interplay between online self-presentation and offline performances help to build an attractive public profile of the political organization outside mainstream politics. The case of DPNI provides a window for analysis of political communication in Russia in the context of emerging opportunity structure for the extreme-right movement actors and at the same time increased state control over the mainstream media.

\section{Internet In Russia and politics}

The success of the social movement is dependent on the set of external variables, such as economic development and technological diffusion. Two specific conditions that make the Internet a particularly important agent of change in Russia are the state control over TV and geographic scale of the 
country. At the same time, it is only a small percentage of Russians who have access to the Internet, and the digital divide is visible along the age, education, residence and social class variables (Lonkila 2008). Level of regional development of the Internet in Russia is characterized by a very distinct "centre vs. regions" and "core vs. periphery regions" divides. With the highest level of the Internet users in Moscow and St. Petersburg, two largest groups are the average developed regions (34 regions) and information deserts (25 regions) (Cooper 2006). The latter are predominantly autonomous republics $(\mathrm{AO})$, where ethnic groups other than Russian make up thy majority of population. In these regions less than 0.9 percent of population is using the Internet ${ }^{3}$ (ibid.).

The peculiar feature of the Russian Internet scene is the high rate of blog-users, some of which are the influential Russian nationalist movement intellectuals (eg. www.krylov.livejournal.com4 or www.tor85.livejournal.com). Markku Lonkila (2008), assessing the potential of future forms of activism in Russia mentions weblog platform LiveJournal as the one which has gained tremendous importance in socio-political debate. In fact, LiveJournal acquired "the aura of intellectual playground" (Gorny 2004: 9), while importance, popularity and influence of some blogs can be even higher than that of the well-maintained web-sites, primarily serving as the source of firsthand information. Unbiased by the mass media frames of interpretation, the blogsphere becomes particularly influential in the political communication when blogs work as the ultimate communication device in the election campaign, 
with the conventional media being under control of the dominating party.

The interrelationship of the Internet and political culture in Russia has been studied by a number of scholars focusing on the use of the websites by the political parties (Semetko and Krasnoboka 2003; March 2004), civic activism networks (Lonkila 2008) or the complexity of the relations between new medium and Russian government (Alexander 2004). Cooper (2006) mentions a rapid diffusion of Internet to politics, and evidence to this is that most of the political parties in Russia have had their own websites. However, in some areas (such as e-commerce) Internet in Russia is underdeveloped, to some extent this can be explained by the distrust of the security and inadequate legislative framework (Cooper 2006).

According to the observations made by Belonuchkin and Mihaylovskaya (2002) , the first political organizations which took advantage of the computermediated communication were marginalized, unregistered political organizations representing different ideologies, and extreme-right organizations among them (Pamyat, Russian National Unity). The use of the Internet by the extreme-right groups in Europe and USA has been investigated from the network perspective (Burris et al. 2000; Tateo 2005) and the contents of the extreme-right websites (Back 2002; Gerstenfeld et al. 2003). Surprisingly, the studies of the extreme-right scene in Russia have not paid due attention to the impact of new communication technology on advances and development of the extreme-right movement. The studies of the Russian extreme-right movement organizations using the Internet as the 
source of data are only starting to emerge. When some scholars focus primarily on the issue of Cyberhate racial contents of the Russian segment of the Internet (Denisova 2007; Rock 2005), others focus on the use of the Internet by the young radical nationalists (Aitamurto 2007)

Aforementioned studies leave unnoticed the communication style of the extreme-right organizations and intersection of online and offline identity of extreme-right movement organization. However, importance of the research delving into the relations between online and offline forms of activism is high (Lonkila 2008). The argument of this study is that the visibility and potential communicative success of the political organization (and its selfpresentation), opposing the current political structure is dependent on the effective interplay between its real life action and online resources (webvisibility and networking). This is especially relevant in the context of the country where other popular media channels are not accessible for the opposition or controlled by a single political party.

\section{Illegal Immigration in Russia - the scale of the issue}

Labor migration processes in Russia are characterized by a very low level of understanding which is reflected in conceptual confusion (Mukomel 2005). For instance, considering the fact, that illegal employment is widespread in Russia, and $90 \%$ of the undocumented immigrants work, two terms illegal immigration and illegal employment are often used as synonyms. Illegal employment and the amount of remittances by immigrants are by far the two main arguments in anti-immigrant discourse (Mukomel 2005). 
In addition to the conceptual confusion, the history of tensions of Russia with some of the current labor exporters is also affecting the attitudes towards immigration among the population in Eastern Siberia and Far East, where Ryzhova (2007) observes the prominent position of $\mathrm{DPNI}^{5}$. The "Chinese question" has been a topic of hot debates since the re-opening of the RussoChinese border in 1988 and some of the first Russian studies on illegal immigration dealt with the analysis of the border regions such as Far East (Zaharova et al. 1994). At that time the idea that the majority of the immigrants in Russia are illegal immigrants (ibid.:12) was articulated in academic discourse.

Subsequent research iterated the "securitization" argument of Zaharova et al. (1994) that accumulation of illegal immigrants in Russia is the consequence of the absence of a full-fledged border (Krassinets et al. 2000) and among other things - non-visa regime for the citizens of the CIS (Yudina 2005). Krassinets and colleagues estimating the scale of illegal immigration in Russia put forth a figure of 4-4.5 million people whereas illegal employment accounts for 3.5-3.8 million people (Krassinets et al. 2000: 82). These figures are compared with the ones provided by the Ministry of Labor and Economics, which announced that the share of the legal foreign labor force accounts for $8-10 \%$ of all the foreign labor force in the country. At the same time the latest research by Yudina (2005) suggests that the average number of illegal immigrants residing in Russia is $1,700,000$, while about one third of them reside in Moscow region. The majority of Muscovites have been found 
to have negative attitude towards migrants, where the most disliked ethnic group was Azerbaijanians (Yudina 2005: 597) and with having a fertile ground for the propagation of anti-immigration discourse the city has become the center for the anti-immigration movement activities.

DPNI has been arguably the most prominent political organization which first began to use anti-immigrant discourse. However development of anti-immigration discourse has received a new and sudden twist in the course of the financial crisis in 2008, when local and national TV channels (such as TVC) suggested that the crisis could make temporary labor migrants overstay their visas and stay illegally in Russia, which may consequently lead to the rise of crime level in the city ${ }^{6}$. The most important event happened in November 2008, when activists of the youth wing of the party "United Russia" organized a series of meetings titled "Our money to our people" with demands of imposing a visa regime with the CIS countries and deportation of the illegal immigrants. Anti-immigration discourse is now attracting political organizations, aligned with the party of power and gains new force with the socioeconomic instability caused by the financial crisis. Such organizations display their willingness to incorporate anti-immigration politicization into their ideological program and thus decrease the political space for the marginalized political organizations.

\section{Extreme-right movement organization and political communication}

For the purpose of this study, we shall consider extreme-right movement as "affinity group or cell-like structure in which small, self-forming 
groups network with other like-minded groups and at times coordinate action and share information, but are not answerable to each other" (Wall 2007: 261). In our study a social movement organization is a nodal point with a degree of centrality in the network of like-minded groups or activist cells, which establishes an interpretive frame for the issues at hand. The cell-like networking structure of the extreme-right movement asks to consider R.Griffin approach to the contemporary extreme right-wing politics, which distinguishes the party-political and groupuscular organization strains. His concept of groupuscular extreme-right movement is defined through introduction of the concepts "rhizome" and "uncivil society" (Griffin 2003: 35). Groupuscular organizations have no proclaimed ambitions to become the "nucleus of mass movement, and instead to take the form of a cadre organization run by a small, self-appointed elite of activists for ideological, organizational or subversive ends" (Griffin 2003: 38). Thus the structure of the extreme right network (both virtual and real) is multi-nodal or "rhizomic", where several organizations may be of central authority for clusters of actors which share some commonalities in ideological framework (eg. anti-systemic, anti-liberal, anti-government).

The first wave of the post-soviet extreme-right organizations worked in isolation from each other and constituted a very loosely connected network. The computer technology enabled existence of a mesomobilization political actor $^{7}$, an actor which could link micromobilization groups for a common campaign, such as the Russian March. DPNI has become a linking 
organization for the actors of the whole spectrum in the extreme-right movement web-communities and individual web-actors (see Zuev forthcoming). It has been a leading organization in preparing protest activities, doing public relations and developing a common interpretive frame for immigration issue. Its innovative feature is multiple affiliations of the members, which helps activists to 'create bridges between organizations, making it easier for information and resources to circulate' (della Porta and Diani 1999:120). Such organization becomes an opportunity for connection between different members of various ideological backgrounds.

Analysis of the political communication style provides important insights about interplay of the website communication and offline media in communicating the goals and ideology of the organization. Political communication style is related to the existing opportunity structure for the extreme right emergence (Goodwin 2007; Rydgren 2005). It is argued in this article that the structure of DPNI has been maintained by its public visibility and online communication due to the emerging opportunity structure of the extreme right.

In order to analyze the political communication style of DPNI E.Goffman's ideas on presentation of self are supplemented by the conceptualizations of political communication style (Jagers and Walgrave 2007; Sokolov 2005). E. Goffman discussion of the self-presentation process in public is crucial in understanding the mechanisms of effective public communication and its importance in understanding the communication 
online has been stressed by scholars of computer-mediated communication (Ellison et al. 2006; Boyer et al. 2006; Miller 1995)

With his dramaturgical perspective Goffman intends to describe 'the techniques of impression management employed in a given establishment, the principal problems of impression management in the establishment, and the identity of inter-relationships of the several performance teams which operate in the establishment' (Goffman 1990: 233). Performance is the key concept in Goffman's approach and refers to the activities which can influence the observers. Goffman distinguishes between information "given" by the performer and 'given off' which marks the difference between the controlled and unintentional impressions communicated by the actors. In the online environment there are more opportunities for misrepresentation (Ellison et al. 2006: 419) and the space for manipulation is great. Manipulation is inevitable part of impression management and mind control, which is especially associated with discourse on the issues 'when the recipients lack the specific knowledge that might be used to resist manipulation' (Van Dijk 2006: 362), such as immigration.

In political communication style of DPNI discursive, cognitive, mobilization and networking dimensions are enmeshed to create an image of movement organization (see table 1). Actions of the movement organization can be classified according to their form of technical realization and aimed meaning. 


\section{Dimensions of Political Communication Style}

\begin{tabular}{|c|c|c|c|c|}
\hline & Cognitive & Discursive & Mobilization & Networking \\
\hline $\begin{array}{l}\text { Form of political } \\
\text { action } \\
\text { (technical level) }\end{array}$ & $\begin{array}{l}\text { Production/Collection of } \\
\text { cognitive resources for } \\
\text { Internet website, printed } \\
\text { newspaper and DPNI-TV } \\
\text { videos }\end{array}$ & $\begin{array}{l}\text { Forming ideological } \\
\text { interpretive frame in } \\
\text { programme documents, } \\
\text { speeches of the } \\
\text { activists, videos of the } \\
\text { meetings and news } \\
\text { narratives }\end{array}$ & $\begin{array}{l}\text { 1)Organization of self- } \\
\text { defense units (vigilantes) } \\
\text { 2) public appearances and } \\
\text { solo performances } \\
\text { (annual Russian March) } \\
\text { 4)Political coalitions with } \\
\text { Duma deputies and } \\
\text { authorities }\end{array}$ & $\begin{array}{l}\text { Communication } \\
\text { between different web- } \\
\text { communities of the } \\
\text { movement }\end{array}$ \\
\hline $\begin{array}{l}\text { Purpose (meaning) } \\
\text { of political action }\end{array}$ & $\begin{array}{l}\text { Providing } \\
\text { exposure to } \\
\text { the information } \\
\text { alternative to the } \\
\text { government view } \\
\text { the issue at stake } \\
\text { (immigration) }\end{array}$ & $\begin{array}{l}\text { Negative evaluation of } \\
\text { "other", positive self- } \\
\text { presentation }\end{array}$ & $\begin{array}{l}\text { 1) involving youth and } \\
\text { training for mainstream } \\
\text { politics } \\
\text { 2) Channeling the protest } \\
\text { in non-violent outlets }\end{array}$ & $\begin{array}{l}\text { 1)Achieving centrality } \\
\text { and visibility in the } \\
\text { web-network, } \\
\text { 2)Achieving credibility } \\
\text { 3)Diffusion of } \\
\text { interpretive frames }\end{array}$ \\
\hline
\end{tabular}

table 1

\section{Data}

In this study the main techniques for collecting data were qualitative network analysis and analysis of the website's production side, which constitutes a part of the hybrid cultural analysis of websites framework (Pauwels 2005). Political movement organization website is one of the few examples of new forms of political communication which creates a completely new pattern of self-presentation. Website of DPNI can be regarded as a profile of organization or its «front», which helps to grasp the organization's position and ideological contents of its activities. Web-site analysis and hyperlink network analysis can be considered as unobtrusive methods for collecting data and are especially relevant when the objects studied are difficult to contact or observed in any other way. For investigation of the interplay between online and offline communication data in this study also come from participant observation of the Russian March and other political rallies organized by DPNI in 2007-2008 in Moscow and Krasnoyarsk. 
Apart of the analysis of the website the empirical data come from analysis of the newspaper "Dozor" and previously conducted research on the Russian ultra-nationalist web-network (Zuev forthcoming).

\section{What is DPNI?}

DPNI's distinct features are flexible membership, loose (leaderless ${ }^{8}$ ) structure and the network of regional representatives in different Russian cities. DPNI emerged as the organization of a new type, allowing mixed membership and political flexibility and in fact possibility of networking between different actors in the ideologically complex Russian ultranationalist scene. Membership in the DPNI would become the common platform for different political styles, rhetoric and visual shapes. The fusion of antiimmigrant and anti-systemic arguments in DPNI's ideology may suit the interests and attitudes of different ultranationalist communities and groups. The principle of mutual recognition reflected in overlapping membership (Diani and Bison 2004) from the start was the tool to make the organization a center of convergence of knowledge production concerning ethnic question.

Formally, DPNI is the organization which has no legal status or official registration as a non-commercial organization or a political party. It is a form of political self-organization based on the volunteer principle. It is difficult to estimate the number of active members and how recruitment actually happens ${ }^{9}$. The structure of the whole organization is maintained through the Internet web-sites of the central www.dpni.org and local branches in different cities and web-forums. Such virtual existence in the Internet makes the 
organization legally invincible, although some individual members and coordinators have been arrested on the grounds of the Article 282 of the Criminal Code for inciting racial, ethnic and religious hatred.

It is hard to provide the main reasons why the authorities have not yet clamped down on DPNI. It is rather a combination of factors that explains the existence of such organization. First of all, it is the fluid nature of the organization and inability of the authorities to punish for the extremist content. Secondly, the argument of Susan Olzak maybe relevant for the Russian case of authorities and protest movement interaction - in order to avoid the growth of large-scale ethnic violence, repressive tactics of the state have to be weakened (Olzak 1998). The existence of such visible organizations and actions, organized by them may be profitable for the state. Olzak argues that «periphery nations with closed or exclusionary systems force protest movements to go underground, become exiled, or engage in outright armed rebellion. Anti-foreigner violence often erupts under these conditions, as does political support for immigrant restrictions and new deportation rules» (ibid: 204). Especially «during political crises, the threat of ethnic victimization becomes more credible» (ibid: 205) when it is important to have outlets for protest in order to avoid the escalation of ethnic violence. It may be true of the Russian case that for the authorities «organized intolerance» is easier to control than «unorganized intolerance» such as ethnic riots.

\section{Dimensions of political communication style}

\section{DPNI discourse}


As Jagers and Walgrave (2007) argue, the content of discourse is the most important element of a political style. The slogan "Law and Order" (Za zakon I poryadok) and its name Movement Against Illegal Immigration make DPNI formally an organization which is similar to new extreme-right parties (Jagers and Walgrave: 2007).

The peculiar feature of DPNI discursive strategy is virtual absence of anti-Semitic and anti-western (anti-American) declarations, which differentiates it from the Old extreme-right of the $80 \mathrm{~s}$ and $90 \mathrm{~s}^{10}$, "eurasianism" of Dugin and anti-americanist leaders (notably Ivan Demidov, the ideological leader of the 'Young Guards'. DPNI has its own "niche" rhetoric, where the main targets are the residents from the former Soviet Union. In anti-immigrant discourse of DPNI residents from the Caucasus states are not differentiated from the residents of the Russian Federation North Caucasus region ${ }^{11}$. This blind packaging of all non-Russians by appearance into one group of undesired "other" makes DPNI discourse implicitly racist. Negative presentation of "Other" is similar to discourse on ethnic minority issues in Europe (van der Valk: 2003) where direct connections are drawn between migrants and crime level.

The avant-garde forces of the foreign expansion are people from the Caucasus states, Central and South East Asia. Each month multimillion diasporas remit huge sums (more than 50bln\$) to their home countries. Most of this money is earned through speculation, drug-sales and other criminal 
ways. (The flyer text of DPNI)

The two constitutive concepts in DPNI discourse are anonymous communities of "Other" - illegal immigrants and "diasporas". Construction of such invisible communities and their multiple number may seem to catalyze social anxiety of the ethnic majority over the immigration issue. Position on immigration is enveloped in the metaphoric relationship of "hosts and guests", where the host is conceptualized as the representative of the dominant ethnic group, the one that possesses power in decision-making and the guest is a potential violator of the established laws and social order.

«We are the hosts in our own house, the host is to make a decision whether to host a guest or not, to decide in which room to host the guest, and for how long. Especially, if someone comes to your house in order to steal things from you or to turn you out of your own house." (DPNI, Goals and Objectives http://www.dpni.org/about/celi i zad)

DPNI sees solution of the illegal immigration problem in radical measures, such as deportation, stating that it is a practice of control in "civilized and democratic states". By locating itself within the framework of civilized and democratic state the organization enhances its positive selfpresentation, which is the usual part of contrasting technique used by the extreme right (van der Valk: 2003). However, DPNI ideologues fail to provide any "clues" for differentiating of legal and illegal immigrants (a subject to 
legitimate deportation). The excerpt below gives some idea who may be considered the potential deportees. The legally grounded demand of measures to be taken against the criminal offenders is augmented by the demand of deporting the illegal immigrants to their home countries and combating illegal employment.

It is necessary to deport from Russia everyone, who has settled here illegally, commits bloody crimes, works in shadow economy and doesn't pay taxes, exploits our Motherland and in future will displace the indigenous population. (ibid.)

As mentioned above the concept diasporas occupies a central position in the expressive repertoire of DPNI. In relation to anti-immigrant discourse it is conceptualized as a numerous, anonymous force behind the illegal immigration. Diasporas are represented by the immigrants who have become naturalized and legalized by receiving citizenship in Russia. In the antiimmigrant discourse of DPNI diaspora becomes a synonym of the organized, tightly-knit social institution which enhances the non-Russian community and thus hypothetically poses threat to the ethnic majority.

Let's remember the reason of the economic success of the diasporas in Russia. It is because they help members of their tribe to earn money: use their services, and buy only from them, bring clients to each other, help to settle down and solve different problems. (DPNI recommends, http://dpni.org/articles/dpni rekom/1325/ ) 
Anti-diaspora argument is also discernible in the National Student Union website, which is associated with DPNI as the youth-student division. Diaspora becomes a general homogenization term and a label in the hate speech in DPNI official documents. It Is used in the political rhetoric to denote other ethnic groups and attribute the "untitled" and nameless character of these groups. In the excerpt below diaspora is associated with the encroachment on the social order established by Russians, and now being under threat. Such disrespect can not be tolerated and hence, discontent with "tolerance" education programs is justified.

...volunteer-forced tolerantization programs were introduced in many Moscow universities. What is tolerance? ....it is when the representatives of the diaspora set their own rules in the dormitories, and you cannot protest about it and let alone regarding them as "a bad diaspora" and "such people should not be here". (These people study in the Moscow universities) ${ }^{12}$

Although DPNI does not advocate direct violence against targeted groups, it provides instructions how a civil person can get a license for firearms. The instructions how to get the firearms are available on the website and in the newspaper "Dozor". The promotion of such civil militarization may be explained in the vein of manipulative strategy aimed at enhancing the public fear and distrust, when everyone has to rely on oneself rather than established law-maintaining institutions, such as police. The arming of the 
civilians and formation of people's self-defense units for patrolling the cities is proposed as a measure of self-organization for the activists to resist the criminal elements and safeguard DPNI events ${ }^{13}$.

DPNI success stories: real life performance

DPNI has been cautious in choosing the places for staging the public performances and protest-objects around which the performance will be staged. The organization's ability to organize the marches, rallies and public recruitment can also be explained by the difficulty in classifying the actions (and propaganda) of DPNI as legally unacceptable and thus punishable by law. The first action of DPNI was mobilization of the local youth for a nationalist meeting in Krasnoarmeysk in 2002. The meeting was organized after the fight between customers of two ethnic groups in the café, which had grown into a full scale conflict in town. This was the first time when the abbreviation DPNI and the logo resembling the traffic sign "NO STOPPING" appeared. The main scenario of DPNI public performance was in presence of DPNI activists or the main coordinator at any minor criminal incident where a conflict involved a Russian and a non-Russian. DPNI does not create antiimmigrant ideology, although extreme-right organizations do extensive mobilization in existing subcultures (Veugelers 1999) converting underground skinheads into public activists. It heats up the apparently everyday conflict, defining it as the situation of crime increased by the inflowing immigrants. It mobilizes the dormant hostile attitudes towards "Other" among the population 
of small towns and later uses the incidents of ethnic unrest as evidence of popular demand for "law and order".

In the following cases, DPNI protest action was based on generally high level of rejection of two minority groups - Azerbaijanians and Armenians in Russia (see Yudina 2005; Zuev 2007). The "Case of Ivannikova" concerned a Russian woman accused of killing an Armenian taxi-driver, who allegedly harassed/flirted with her. After she was found innocent DPNI leader A. Belov awarded her with a money prize "For Courage"14. Another case was the protest against the erection of the monument to Geydar Aliev - former Azerbaijanian president in Moscow organized by the Azerbaijanian community. Information about these cases was provided for the media and DPNI hired lawyers to supervise the process of preparing protest letters from the general public to the Parliament deputies.

DPNI is far from being a militant organization, based on the leadership cult, as it was the case with the Russian National Unity. Its mode of action the use of public agitation to mobilize the dissatisfied population and to channelize public discontent at the victimized ethnic minorities was demonstrated during the ethnic riots in Kondopoga in 2006 and Stavropol in 2007. The events in the small town of Kondopoga in Karelian Republic were the key catalyst of the DPNI publicity in 2006. The success of the organization was based on the ability to break through the information blockade of the mass media about the events in Kondopoga. Due to the agitation work of DPNI activists the criminal fight between the Russians and 
the Chechens in a restaurant resulted in the ethnic conflict with mass-scale property destruction, stone throwing, civil disobedience and consequent evacuation of the Chechens from the city. The slogan - "Kondopoga is the hero city $^{15}$ " became one of the creative trademarks of DPNI and a T-shirt bestseller in the DPNI's Internet shop. Kondopoga was declared the symbolcity of the Russian resistance and became a synonym for ethnic riots in Russia or in fact an indicator, that ethnic tensions in small provinical cities are much beyond the control of the local authorities.

Tragic events in Kondopoga showed the majority of Russian citizens total inefficiency of the system, built within the framework of the Constitution of 1993, inability and unwillingness of the ruling power to guarantee the Russian citizens their right to live. (Kondopoga - the symbol of awakening of the Russian people http://benzol.us/index.php?right+133)

The excerpt demonstrates that creation of new "symbols of resistance"constitutes an important part of the symbol-production process. The symbols as "Kondopoga" are "sign-equipment" for generation of cognitive definitions, in line with the movement's goals. Production of symbols helps organization to create resources, which can be easily accessed and presented to the public for arousing discontent and facilitating mobilization. Kondopoga as the image of a small city, became the symbol of public unrest based on ethnic tensions and is promoted by DPNI as the symbol of ethnic crisis, which may become reality for many other small towns. DPNI links the 
ethnic tensions in Kondopoga with its anti-establishment stance, persuading the audience to take the assertion, that the governement is illegitimate as it is incapable to protect the citizens. The excerpt gives off the other aim of the organization - discrediting the "party of power", which is hidden within a broader anti-immigration argument. Attempts to discredit the "United Russia" are also made through production of caricature stickers, T-shirts and imagery, which are targeted for the youth segment of DPNI activists.

Russian Marches organizied in 2005-2008 have been one of the major public protest events organized by DPNI in cooperation with its often changing nationalist movement partners (ESM, NDPR, Velikaya Rossiya, $\mathrm{KRO}$, RONS, Slavyansky Soyuz). DPNI as a mesomobilization actor of the Russian March resorted to non-conventional methods of communication with the activists, such as collective SMS-service.

If you would like to receive more information about the prepared event by means of SMS, to learn about the exact time and place of the meeting, please fill in the form leave your phone number, to which you would like the messages to be sent (Subscribe to the news about the Russian March, 2007 )

The ability to organize the event using primarily web-resources and effectively mobilize several thousand activists of various ideological background and groups gives evidence of the organization's ability to use all available communicattion channels to connect with its members and sympathisers. SMS-information service is useful for the oppositional political 
movement to create the virtual link between the chief coordinating actor and activists. It can be instrumental for the activists to be constantly updated regardless of their spatial location, especially when the meeting is not sanctioned by the authorities. SMS-alert service confirms that DPNI is ahead of other political organizations in taking advantage of communication technologies and finding its way to communicate with the possible segment of its followers, who do not have constant access to the Internet.

\section{Expressive equipment of DPNI website}

In this part of the article the website analysis is intended to identify specific features of the organization, which can qualify as its «expressive equipment» (Goffman 1990) used for successful presentation of self. Important element of the permanent performance visible for the audience is the website: its interface, position in the web-network and interactivity features, It is essentially a front of the organization's performance. While control of the organization's front and guarding the secrets of the performance are the activities which increase solidarity of the members.

DPNI is the leading web producer of information regarding the immigrant question in Russia. It can be defined as a movement organization with the goal of producing racially charged ideas and information and primarily youth- oriented mobilization. DPNI possesses the anti-system element of "delegitimizing the "system" by opposing fundamental value of the existing political regime (Capoccia 2002), which is "multi-ethnicity"/ "federalism". To some extent, DPNI's communication strategy is similar to its 
main adversary's - the Human Rights organization SOVA-center ${ }^{16}$ monitoring and producing knowledge on a single-issue and making it available on the Internet. The bias of the knowledge produced by DPNI is that it is only related to the cases of crime committed by the immigrants or nonRussians in Russia or directly affecting Russians. DPNI is linked to Altermedia website, which produces and distributes information with racist content worldwide.

DPNI does not reserve production of knowledge relevant to its objectives only for the members; it also allows non-members to participate in the process of information production. Adding news is one of the interactive features on the website and is open to anyone but is limited within the range of topics which are listed on the web-site. Multi-language (French, German and English) online translation facility on the website makes the information available to a wider international audience and establishes the image of organization as being integrated in the European anti-immigration discourse. The organization is clearly aware of the fact that its success lies in effective diffusion of knowledge across national borders.

DPNI unlike many extreme-right organizations in Russia exercises manipulation not only through text and talk, but through visual messages. One of the innovative features of DPNI knowledge diffusion is its own "internal media" - TV channel DPNI-TV. With the increasing number of users with high-speed Internet the alternative TV news channel beyond control of the government becomes a powerful tool in agitation by providing information 
which challenges the dominating media and ideological codes of the state owned channels. Three top categories in the DPNI-TV archive are street actions, "weekly panorama" and the Balkan war. The videos, which are featured prominently on the home page intend to discredit the mainstream media and have strong anti-Putin rhetoric ("You will not see this on TV"), intensify distrust in the authorities and current immigration policy ("Putin's plan in reality") and enhance the martyr image of the central activists in DPNI ("Attempted murder of A.Belov"). DPNI-TV is a good example how extremeright organization takes advantage of Web 2.0, where production of contents is a collaborative and participatory project. Within the new rhetoric of democratization users are not only consumers of videos, they also become non-member activists who produce and post their own videos.

One of the powerful devices in the expressive equipment of DPNI is communication of "suffering for the cause". Certain degree of repression of the movement organization from the state (or attacks by anti-fascist movement activists) can bring "points" to the organization in the political struggle. According to Rydgren (2005: 425) "repression may lead to enhanced mobilization because it reinforces the movements' collective identity". The website of DPNI contains a separate section called Political repressions, with the list of the ultranationalist movement activists, who were imprisoned or accused of inciting racial hatred. Creating images of sacrifice for the ideals of the movement and the scale of sacrifice helps to intensify the protest and works as an "anti-political establishment strategy" (ibid: 425). 
Arrests, detentions, police searches, attacks and beatings of the members and the leader A.Belov contribute to the intensification of the martyrdom image which is used to escalate the public and media attention. In 2006 the murder of one of the members of DPNI was turned into a public performance, when a march with flags and torches to commemorate the death of one of the comrades was organized by the activists ${ }^{17}$. The news of the arrest of the DPNI leader a few days prior to the Russian March in 2007 could also be a skillful orchestration created to attract more young participants to the protest rally and display resistance of the organization to the system. As Sokolov argues, «political style of any extreme-right organization is defined by the nature of capital, possessed by its followers» (Sokolov 2006: 74). For instance, the capital can be acquired through dramatization of the work of organization, by «making invisible costs visible» (Goffman 1990: 42). Political repressions have become the expressive equipment of a marginalized political organization in Russia, stigmatized by the authorities. It refers to the tradition of punishment for the political disagreement in the Soviet times, which allows a "political outcast" to enhance its political capital on the ground of its «anti-systemic» character and receiving an aura of an antiestablishment fighter for justice.

The website section Fund of Open Contributions (the former How to help) displays the financial transparency of the support and resources possessed by the DPNI. The reports are open to any visitor and provide the monthly financial reports with detailed budget. The goal of the reports is 
communication of the visibility of organization's moves, which require expenditure and demonstration of the transparency of the financial state of affairs. The statement made by such reports is that the money invested by the sympathisers is not wasted and goes to good causes (eg.help to the family of the murdered activist, salary of the lawyers). The reports may help to avoid accusations in non-purposive waste of money and support the loyalty of the activists to the budget of the organization. Certainly, there are no ways to check the accuracy of the book-keeping of such organization since money are sent via different methods including web-money (yandex.money), conventional money-orders or bank transfers. But such transparency approach works positive on the organization political image seen by common people, living in the cultural context of the corruption, unpurposeful waste of the state funds and complete lack of accountability of the political organizations in Russia. The main challenge in the analysis of the political movement organizations in Russia is identifying the origin of the stakeholder which demands the "progress report". Veugelers analyzing success of extreme-right organizations mentions, that "non-selfish motivations such as guilt, idealism and identity also stimulate contributions from activists, campaigners, fund-raisers" (Veugelers 1999: 87) other possible sources of important contributions may be "a union, wealthy donors, an interest group, sponsors in banking or business, a foreign power with an interest in the party's success"(ibid, 87). On the basis of available data, it is hard to establish whether DPNI is the commercial project of the anonymous 
sponsors, personal adversaries of the current political situation in Russia or if it is an organization, which exists solely on the volunteer's donations and ideological enthusiasm of the activists' elite.

Position in the web-scape and in real life: studying DPNI hyperlinks DPNI's communicative potential in the extreme-right movement is built on the interplay between its Internet self-presentation and offline performance. To identify the authority of DPNI in the extreme-right webnetwork the data on hyperlink analysis was used (Zuev forthcoming). DPNI was established to have centrality in the extreme-right web-network. It collected the highest number of in-links (22) from the initial list of 63 analyzed web-sites, and is the organization which doesn't have many visible out-links to any of the web-actors which direct hyperlinks to DPNI. Online it is with a few exceptions an 'in-link' movement organization, not openly collaborating with any of the web-actors or web-communities of the extreme-right network.

The number of hyperlinks incoming to the DPNI web-site indicates for the users credibility of the information which the site provides and the quality of the website (Park and Thelwall 2003). The fact that DPNI site does not provide any out-links to other organizations, creates the feeling that it must be the ultimate information database and first point of reference on the antiimmigration issue for the multitude of actors in the extreme-right web-network in Russia. It becomes the final destination in getting the «alternative information» concerning the ethnic issues. Credibility of the website and its incoming centrality are interrelated and as Park and Thelwall conclude: «the 
more credible the website, the more incoming links the web-site has. The more incoming links, the more visitors the website has, and vice versa» (Park and Thelwall 2003). One can imagine that the more visitors the web-site has, the more people are potentially exposed to the anti-immigration discourse and ideas of Russian extreme-right.

The nature of out-links from the DPNI website is that they are not as explicit as in other extreme-right organizations' websites. They can be divided into links to coalition groups (web-hubs) and links to the organization "service sites". This strategy of indirect links through a web-hub allows DPNI not to create explicit links to other members of the movement network. This linking strategy is also typical for anti-immigration (nativist) groups in the USA (Sohoni 2006: 843).

By means of the content analysis of DPNI websites' out-links one can assess its online visibility to identified web-communities (Zuev forthcoming). DPNI's characteristic feature is its contribution to creating coherent online movement network-centrality in the ultranationalist movement and prominent position in reputation hierarchy. Its collection of in-links (see Appendix 1) represents the full range of the Russian extreme-right web-scape. The hyperlinks also reveal links of DPNI with nationalist parties and individual deputies' websites. The link to the party "Velikaya Rossiya" is not accidental, as the leader and Duma deputy A. Savelyev is the member of DPNI. The party NDPR headed by Duma deputy N. Sevastyanov, and ex-member of LDPR deputy N. Kuryanovich and most importantly "Congress of Russian 
Communities"(KRO), headed by N. Rogozin ${ }^{18}$ also have formal links to DPNI and have participated in the protest actions and Russian March organized by DPNI. Visibility of DPNI and its adult political segment support is also apparent at the Russian March where it forms the most numerous avantgarde column and plays central role in the organization and agitation for the Russian March.

The systematization of links collected by DPNI leads to conclusion, that it is an important bridge between several existing extreme-right webcommunities (see Appendix 1) and that anti-immigration rhetoric is explicitly supported by the political elite and a big group of activists. DPNI integrates youth dimension of underground subcultures (Russian neo-pagans and NS/WP communities) and adult political culture (political parties, visible public figures and deputies of Russian Parliament). Analysis of hyperlinks gives an important approximation of the offline connections between actors, but limitations of hyperlink analysis must be conceded. Web-links, although an important indicator of the virtual connection between the web-actors and organizations (often insignificant in number) also do not fully represent the actual collaboration patterns. This is somewhat contradictory to the argument made by Rock (2004) that Russian virtual reality represents the offline reality. For instance, "Slavyansky Soyuz" headed by D. Demushkin never mentions DPNI in its friend-links, but the two organizations and their leaders often appear together at the rallies, nationalist meetings and have been the main participants of the Russian March (2005-2008) and seem to be informal 
friends or soratniki. Russian online reality represents a fraction of interactions of the movement organization, and investigating the informal offline connections exposes its allies and opponents.

Therefore, when assessing the organization's networking patterns and identifying its allies it is useful to rely both on the hyperlinks structure and offline activities, which reveal the actual communication and "overlapping views of the same reality" (Lonkila, 2008: 1145). The hyperlinks in the case of DPNI expose its authority and reputation in production of the updated and alternative information on immigration issue, with an interpretative frame different from the discourse of the official mass media. However, absence of hyperlinks between the extreme-right organizations and other nationalists cannot be considered as a display of mutual disagreement or enmity.

\section{Conclusion}

According to C. Mudde (2005), in contrast to political parties extremeright organizations present considerable difficulty for assessing their importance and strength. Nevertheless, the potential impact of the non-party organization which stands in opposition to the government can be assessed on the ground of its communication online and offline. Four main dimensions of the political communication style of DPNI (table 1) can be outlined as follows. Firstly, one can distinguish the cognitive dimension, which is realized through production of information on issue of immigration and related topics ('adverse effects') via available communication media (Internet (YouTube). Secondly, it is discursive dimension, which supposes formation of ideological 
frames of the immigration issue, where the core animosity dychotomy is of the victims (activists and Russian people) and adversaries (diasporas of "Other" and establishment). In this dimension DPNI's specific emphasis is put on crime committed by "Other" against the ethnic majority. The third dimension concerns the discernible ways of mass mobilization and mobilization of resources. Russian March and other contentious gatherings make up the publicity luggage of the organization, in this aspect demonstrating political elite support is instrumental. Organization can also promote production of "sign-equipment" which can be later used for mobilization (such as "Kondopoga"). Finally, networking dimension, which concerns the organization's website communicative performance in the Internet network. The centrality of the organization in the offline movement network is aided by the centrality of the organization's website online, which both contribute to potential diffusion of the advertised issues and interpretive frames. In the extreme-right movement DPNI fulfills its networking function as a "bridge organization" for potential political training of the young volunteers and their further involvement in the "adult" political organizations (parties).

DPNI is ambitious to present itself as an alternative social order upkeeping entity, but without the wide support of the authorities or the party of power its resources are insufficient. It is hardly a challenger to United Russia nor any mainstream parties, which often employ populist rhetoric (LDPR, CPRF). But challenging the mainstream political actors and competing with 
them is not the goal of the organization. Political space for the extreme right in Russia is limited «because nationalism informs the ideology of most dominant actors and because historical fascism is largely discredited» (Minkenberg 2002: 362). Political significance of DPNI is in its function of political incendiary and mobilizer which through available means involves youth - the most uncontrollable political force. Although it does not possess resources which will help to gain mass following it is able to be the visible political actor, which provided due opportunities and chance can become an influential non-party actor by crystallizing and radicalizing immigration issue, which may be later found attractive and adopted by mainstream political actors and organizations.

\section{Appendix 1}

List of organizations and web-communities which have links to DPNI

\begin{tabular}{|l|l|l|}
\hline $\begin{array}{l}\text { Official parties } \\
\text { and deputies }\end{array}$ & $\begin{array}{l}\text { Name of the } \\
\text { web resource }\end{array}$ & URL \\
\hline & $\begin{array}{l}\text { Nazionalno-Derzhavnaya } \\
\text { Partiya Rossii }\end{array}$ & $\underline{\text { www.ndpr.ru }}$ \\
\hline & $\begin{array}{l}\text { Website of the deputy N. } \\
\text { Kuryanovich }\end{array}$ & $\underline{\text { http://kuriyanovich.ru/ }}$ \\
\hline & Velikaya Rossiya Party & $\underline{\text { http://www.velikoross.ru/ }}$ \\
\hline NS/WP community & $\begin{array}{l}\text { Rodina. Kongress Russkyh } \\
\text { Obshin (Congress of Russian } \\
\text { Communities) }\end{array}$ & $\begin{array}{l}\text { National Socialist Portal } \\
\text { "White Wolves" }\end{array}$ \\
\hline
\end{tabular}




\begin{tabular}{|c|c|c|}
\hline & Spolohi & http://www.spolohi.front.ru/ \\
\hline & $\begin{array}{l}\text { Narodnaya } \\
\text { Partiya }\end{array}$ & www.nnpr1.rusrepublic.ru \\
\hline & NS/WP Portal & http://nswap.info/ \\
\hline & Brangolf web-zine & http://brangolf.cjb.net/ \\
\hline \multirow[t]{3}{*}{$\begin{array}{l}\text { Neopagan } \\
\text { (Rodnovery) }\end{array}$} & $\begin{array}{l}\text { Vedarya, the site of the White } \\
\text { Internationalists }\end{array}$ & www.vedarya.sled.name \\
\hline & Velesova Sloboda & $\begin{array}{l}\text { http://www.velesova- } \\
\text { sloboda.org/start/main.html }\end{array}$ \\
\hline & Slavic Library & www.slav.olegern.net \\
\hline \multirow[t]{5}{*}{$\begin{array}{l}\text { Russian Orthodox } \\
\text { Fundamentalist } \\
\text { and Empire } \\
\text { Monarchist }\end{array}$} & $\begin{array}{l}\text { Soyuz Russkogo Naroda } \\
\text { and web-newspaper "Rus } \\
\text { Pravoslavnaya" (Orthodox } \\
\text { Russia» }\end{array}$ & $\frac{\text { http://www.rusnar.ru }}{\text { http://www.rusprav.org }}$ \\
\hline & Russian Empire Society & http://www.rus-imperia.info \\
\hline & Russkoye Nebo & www.rus-sky.com \\
\hline & $\begin{array}{l}\text { Za russkoye delo (For the } \\
\text { Russian Cause) }\end{array}$ & www.zrd.spb.ru \\
\hline & 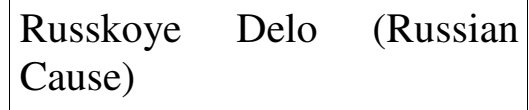 & www.russkoyedelo.org \\
\hline \multirow[t]{5}{*}{ Other websites } & $\begin{array}{l}\text { Russian Nationalist Power } \\
\text { "2 against 1" }\end{array}$ & $\begin{array}{l}\text { http://www.nationpower.net1 } \\
\text { 4.org/index.htm }\end{array}$ \\
\hline & $\begin{array}{l}\text { Russian March Information } \\
\text { Page }\end{array}$ & www.rusmarsh.org \\
\hline & Russian Nationalism & www.nationalism.org \\
\hline & $\begin{array}{l}\text { Obshestvennoye } \\
\text { Obyedineniye Rus }\end{array}$ & $\begin{array}{l}\text { www.angelfire.com/folk/bure } \\
\text { nkovv/ }\end{array}$ \\
\hline & $\begin{array}{l}\text { web-hub «The Ring of } \\
\text { Patriotic resources» }\end{array}$ & www.rossija.info \\
\hline
\end{tabular}

\section{References:}


Aitamurto, K. (2007) Conceptualizations of fascism and anti-fascism on Rodnoverie Internet forums. in Vanhalla-Aniszewski, M. and Lea Siilin (eds) Voices and Values of Young People - representations in Russian Media. Aleksanteri Series 6. Helsinki University.

Alexander M. (2004) The Internet and Democratization: The Development of Russian Internet Policy. Demokratizatsiya. 12 (4) 607-627

Back, L. (2002) Aryans reading Adorno: cyber-culture and twenty-first century racism. Ethnic and Racial Studies. 25(4): 628-651

Belonuchkin G., Mihaylovskaya E. (2002) Politicichesky segment rossiyskogo Interneta: ego razvitiye i perspektivy. In (ed. Semenov I.) Internet I Rossiyskoye obshestvo. Moscow: Gendalf

Boyer L., Brunner B.R. And Charles T. (2006) Managing Impressions in a Virtual Environment: Is Ethnic Diversity a Self-Presentation Strategy for Colleges and Universities? Journal of Computer-Mediated Communication. 12 (1) URL: http://jcmc.indiana.edu/vol12/issue1/boyer.html (visited 20.12.2007)

Braun A. and Scheinberg S. J. (eds.) (1997) The extreme right: Freedom and security at risk Boulder, CO: Westview Press. 
Burris, V., Smith, E. and Strahm, A. (2000) White supremacist networks on the Internet. Sociological focus. 33(2) 215-235

Cappocia G. (2002) Anti-System Parties: a conceptual reassessment. Journal of Theoretical Politics 14 (1) 9-35

Cooper J. (2006) The Internet as an Agent of Socio-Economic Modernisation of the Russian Federation. In Kangaspuro M., Smith J. (eds.) Modernisation in Russia since 1900, Helsinki: Finnish Literature Society

della Porta D. and Diani M. (1999) Social movements. An Introduction. Blackwell Publishers.

Denisova, A. (2007) Cyber H8 - otvetny udar. In Verhovsky A.(ed.) Yazyk vrazhdy protiv obshestva. Moscow: SOVA

Diani M., Bison I., (2004) Organizations, coalitions and movements. Theory and Society. 33: 281-309

Douglas K.M., McGarty C., Bliuc A-M., Lala G. 2005) Understanding Cyberhate: Social competition and Social Creativity in Online White Supremacist Groups. Social Science Computer Review. 23: 68-77

DPNI: Itogi raboty za 2002-2006 (DPNI: progress report for 2002-2006) 
05.06.2008)

Dubet, F. (2004) Between a Defence of Society and a Politics of the Subject: The Specificity of Today's Social Movements. Current Sociology 52(4) 693 716

Eatwell R. (2002) The Rebirth of the Right-Wing Charisma? The cases of Jean-Marie Le Pen and Vladimir Zhirinovsky. Totalitarian Movements and Political Religions 3(3) 1-23

Ellison N., Heino R. and Gibbs J. (2006) Managing Impressions Online: SelfPresentation Processes in the Online Dating Environment. Journal of Computer-Mediated Communication 11(2) 415-441

Eyerman, R. and Jamison, A. (1991) Social movements. A cognitive approach. University Park, PA: Pennsylvania State University Press

Gerhards J. and Rucht D. (1992) Mesomobilization: Organizing and Framing in Two Protest Campaigns in West Germany. The American Journal of Sociology. 98 (3) 555-596

Gerstenfeld, et al. (2003) Hate online: a content analysis of extremist Internet Sites Analyses of Social issues and Public Policy 3(1) 29-44 
Goffman E. (1990) The presentation of self in everyday life. Penguin books.

Goodwin M.J. (2007) The extreme right in Britain: Still an "Ugly Duckling" but for how long? The Political Quarterly. 78 (2) 241-250

Griffin R. (2002) The incredible shrinking ism: the survival of fascism in the post-fascist era. Patterns of Prejudice. 36(3) 3-8

Griffin R. (2003) From slime mould to rhizome: reflections on the groupuscular right. Patterns of Prejudice. 37 (1) 27-50

Gudkov L., Dubin B. (2005) Svoeobraziye russkogo nazionalizma. Pro et Contra. 9-10 6-24

Hanley S., Szczerbiak A., Haughton T., Fowler B. (2008) Sticking Together. Explaining Comparative Centre-Right Party Success in Post-Communist Central and Eastern Europe. Party Politics. 14 (4) 407-434

Hate Crime in Russia: Brief Analysis, Statistics, Recommendations (2006) http:///xeno.sova-center.ru/6BA2468/6BB4254/8187B08 (accessed 12. 05.2008)

Hockenos P. (1993) Free to Hate: The rise of the Right in Post-Communist Eastern Europe. New York:Routledge 
Hooghe M., Teppe W. (2007) Party profiles on the web: an analysis of the logfiles of non-partisan interactive political interest in the 2003 and 2004 election campaigns in Belgium. New Media \& Society. 19 (6) 965-985

Jagers J., Walgrave S. (2007) Populism as political communication style: an empirical study of political parties' discourse in Belgium. European Journal of Political research 46 319-345

Krassinets E., Kubishyn E., Tyuryukanova E. (2000) Nelegalnaya migrazia v Rossii (Illegal immigration in Russia). Moscow:Academia.

Lacquer, W. (1993) The Rise of the extreme Right in Russia. New York: Harper Collins Publishers.

Likhachev V. (2002) Pravye radikaly v sovremennoy Rossii: ideologiya, deyatelnost i vzaimootnosheniya s vlastyu.

URL: www.panorama.ru/works/patr/lih-list.html (visited 12.01.2009)

Lonkila, M. (2008) The Internet and Anti-military Activism in Russia. EuropeAsia Studies 60 (7) 1125-1149

Mathyl M. (2002) The National-Bolshevik Party and Arctogaia: two neo-fascist groupuscules in the post-Soviet political space. Patterns of Prejudice. 36(3) 
Miller H. (1995) The presentation of self in electronic life: Goffman on the Internet. Paper presented at «Embodied Knowledge and Virtual Space» Conference Goldsmiths' College, University of London.

Minkenberg M. (2000) The Renewal of the Radical Right: Between Modernity and Anti-modernity. Government and Opposition. 35(2) 170-188

Minkenberg M. (2002) The Radical Right in Postsocialist Central and Eastern Europe: Comparative Observations and Interpretations. East European Politics and Societies. 16 (2) 335-362

Minkenberg M. (2003) The West European radical right as a collective actor: Modeling the impact of cultural and structural variables on party formation and movement mobilization. Comparative European Politics. 1 149-170

Mudde C. (2005) Racist Extremism in Central and Eastern Europe. East European Politcs and Societies. 19(2) 161-184

Mukomel V. (2005) Ekonomika nelegalnoy immigrazii. Demoscope weekly. 92

Nazionalisty podveli itogi parlamentskyh vyborov (2007) 
http://dpni.org/articles/novosti dp/6994/ accessed 08.06.2008

Olzak S. (1998) Ethnic protest in core and periphery states. Ethnic and Racial Studies. 21 (2) 187-217

Park, H. W. and Thelwall M. (2003) Hyperlink Analyses of the World Wide Web: a review. Journal of Computer-mediated communication. 8(4) URL: http://jcmc.indiana.edu/vol8/issue4/park.html (visited 12.01.2008)

Parland (2005) The extreme nationalist threat. The growing influence of Western Rightist ideas. London: Routledge.

Pauwels, L. (2005) Websites as visual and multimodal cultural expressions: opportunities and issues of online hybrid media research. Media, Culture and Society. 27 (4): 604-613

Pedahzur A., Weinberg L. (2001) Modern European Democracy and Its Enemies: The threat of the Extreme Right Totalitarian Movements and Political Religions. 2(1) 52-72

Puuronen V., Safin R., Salagajev A., Sotkasiira T. and Turijanski I. (2007) Venalaisten nuorten rasismi. Finnish Review of East European Studies. 4. 313 
Ramet S. P.(1999) Values and behaviors of organized intolerance in postcommunist Central and Eastern Europe in Ramet S. (ed.) The radical right in Central and Eastern Europe since 1989 University Park, PA: Pennsylvania State University Press

Ramet S. (ed.) (1999) The radical right in Central and Eastern Europe since 1989. University Park, PA: Pennsylvania State University Press.

Raschke J. (1985) Soziale Bewegungen. Ein historisch-systematischer Grundriss. Frankfurt a.Main: Campus

Rock, S. (2004) Racism and Xenophobia in Virtual Russia. In Racism and Human Rights. (ed. Walden,R.) NLD: Brill Academic Publishers. pp.101-124

Rydgren J. (2005) Is extreme right-wing populism contagious? Explaining the emergence of a new party family. European Journal of Political Research. 44 pp. $413-437$

Ryzhova N.P. (2005) Blagoveshensk - forpost imperii ili zona svobodnoy ekonomiki? In (eds.) Dyatlov V., Ryazanzev S. Stabilnost I conflict $v$ Rossiyskom Prigranichye, Sibir I Kavkaz. Etnopoliticheskiye prozessy v Sibiri I na Kavkaze. Moscow 
Shenfield, S. (2001) Russian Fascism. Traditions, Tendencies, Movements. Armonk, New York: M.E. Sharpe

Sohoni, D. (2006) The "Immigrant Problem". Modern Day nativism on the Web. Current sociology. 54(6):827-850

Sokolov M., (2004) Teatr Prevrasheniy: Analiz transformazii russkogo radikalno-nazionalisticheskogo dvizheniya. In (ed.) Vasilyev S. Aktualniye Problemy trnasformazii sozialnogo prostranstva. Saint-Petersburg, Leontyevskiy Zentr. 295-322

Sokolov M. (2006) Russkoye Nazionalnoye Edinstvo: analiz politicheskogo stilya radikalno-nazionalisticheskoy organizazii. POLIS. Politicheskiye issledovaniya. $1.67-77$

Subscribe to the news about the Russian march (2007) http://dpni.org/articles/russkij ma/4987/ (URL accessed 05.06.2008)

Szcocs L. (1998) A tale of the unexpected: The extreme Right vis-a-vis Democracy in Post-Communist Hungary. Ethnic and Racial Studies. 21 (6) 1096-1115

Tateo L. (2005) The Italian extreme Right on-line Network: an exploratory Study using an integrated Social Network Analysis and Content Analysis 
Approach Journal of Computer-Mediated Communication 10 (2)

Tolz V. (2003) Right Wing extremism in Russia: the dynamics of the 1990s. In Merkl P. H. and Weinberg L. (eds.) Right-wing extremism in the twenty-first century London and Portland: Frank Cass

Umland A. (2002) Toward an Uncivil Society? Contextualizing the Decline of Post-Soviet Russian Parties of the Extreme Right Wing. Demokratizatsiya. 10(3) $362-91$

Umland A. (2005) Concepts of fascism in Contemporary Russia and the West. Political Studies Review 3 (1) 34-49

Umland, A. (2006) Tri raznovidnosti postsovetskogo fashisma (Three types of the post-soviet fascism). In Russky Nazionalism: ideologiya i nastroyeniye (Russian Nationalism: ideology and mood). Moscow: SOVA pp.223-263

Van der Valk I. (2003) Political discourse on ethnic minority issues: a comparison of the right and the extreme right in the Netherlands and France. Ethnicities. 3(2) 183-213

Van Dijk T. (2006) Discourse and Manipulation. Discourse \& Society. 17 (3) $359-383$ 
Varga M. (2008) How political Opportunities Strengthen the Far-Right: Understanding the Rise in Far-Right Militancy in Russia. Europe-Asia Studies. 60 (4). $561-579$

Veugelers J.W.P (1999) A challenge for Political Sociology: The Rise of FarRight Parties in Contemporary Western Europe. Current Sociology 47 (4) 78 100

Wall M.A. (2007) Social movements and email: expressions of online identity in the globalization protests. New Media \& Society. 9 (2) 268-277

Williams C. and Hanson S.E. (1999) National-Socialism, Left Patriotism, or Superimperialism? in Ramet S. (ed.) The radical right in Central and Eastern Europe since 1989 University Park, PA: Pennsylvania State University Press

Yudina T. (2005) Labour Migration into Russia: The response of State and Society. Current Sociology. 53(4) 583-606

Zakharova O., Mindogulov V. Rybakovskiy L. (1994) Nelegalnya immigrazia v prigranichnyh rayonah Dalnego Vostoka. (Illegal immigration in the border areas of the Far East). Sotsis (Soziologicheskiye Issledovaniya). 12. 
Zuev D. (2007) Nuorten "toista" koskevat asenteen Krasnojarskissa. Finnish

Review of East European Studies. 4 . 27- 44

Zuev D. (forthcoming) Russian ultranationalist movement in Internet in ed. V.

Puuronen "Living with difference in Russia"

1 Another example of discrepancy between high level of opposition to immigration and absence of successful extreme right party may be Greece (Goodwin, 2007).

2 The year 2005 may be considered as the Russian extreme-right movement «regeneration point», it was the first time of large scale celebration of National Unity Day conducted as the Russian March. It attracted predominantly youth activists and has become an annual political gathering for the extremeright expression of solidarity across Russia.

3 Some of these regions are also among the Russia's least populated ones.

$4 \mathrm{~K}$. Krylov is the editor of the Agency of Political News, www.apn.ru and one of the chief ideologues of the Russian March.

5 DPNI activists were prominent in organizing anti-immigration protest-gatherings in the central square of Krasnoyarsk and near the «Chinese trade center» in 2007.

6 Federal Migration Service did not register mass flow of immigrants out of Moscow. News Report at Radio «Echo Moskvy».11.12.2008

7 For fuller analysis of micromobilization and mesomobilization actors see Gerhards and Rucht, 1992

8 In the case of DPNI, public speaker of DPNI is A.Belov, who is usually mentioned as "coordinator» of central organizing committe and is responsible for DPNI public relations. In this study A.Belov is refferred to as «leader».

9 Recruitment is often organized on the spot during the meetings or rallies, when sympathizers of DPNI can join the organization at a make-shift registration point.

10 Such organizations as Pamyat or Russian National Unity (RNE)

11 All residents of the North Caucasus, regardless of their appearance are treated with equal degree of security-based suspicion at the arrival in Moscow airports, when they are searched repeatedly.

12 Accessed 14 November 2007 from http://www.united-students.org/node/132

13 http://www.dpni.org/articles/sobitiya/80/ (URL accessed 10.03.2008)

14 "Aleksandra Ivannikova received 50.000 roubles as award from a nationalist organization for killing an Armenian, who was giving her a ride in his car and according to the legal case data, tried to rape her." News report at Radio Echo Moskvy http://echo.msk.ru/news/260309.html. (URL accessed 05.06.2008)

15 Hero-city (gorod-geroy) is the honorary status given to a selection of Russian cities, signifying the important role of the cities in the resistance to the German troops during the Second World War

16 SOVA-center is the organization collecting and distributing information on hate crime and xenophobia in Russia

17 Newspaper «Dozor» 5, 2007

18 Duma deputy, former Duma representative in NATO and head of the Duma's International Committee, head of the political party "Rodina" which in 2003 gained 9.1\% of electoral support in elections to Russian Parliament. 